\title{
BIOLOGICAL STUDIES ON RED PALM WEEVIL, Rhynchophorus ferrugineus (OLIVIER) REARED ON SEMI - ARTIFICIAL DIET IN EGYPT
}

\author{
EL-DEEB, M.A. ${ }^{2}$; M.K.A. ABBAS ${ }^{1}$; M.M. \\ EL-ZOHAIRY2; AND OLFAT, E. ARAFA ${ }^{1 *}$. \\ 1. Plant Protection Res. Inst., ARC, Dokki, Giza, Egypt. \\ 2. Plant Protection Dept., Fac. Agric., Zagazig Univ., Egypt.
}

(Manuscript received 6 August 2018)

\begin{abstract}
$\mathrm{R}$ ed palm weevil, Rhynchophorus ferrugineus (Olivier) was reared in the laboratory during 2011 under cooling incubator at $30 \pm 1 \mathrm{C}^{\circ}$. and $85 \pm 5 \%$ in the Plant Protection Department, Faculty of Agriculture, Zagazig University,Egypt on semi-artificial diet (potato diet) , all developmental stages were recorded including female and male longevity as follows: The egg incubation period ranged from 2-4 days with a mean of 3 days and the percentage of hatchability was $88 \%$.The total larval period ranged from 45 to 55 days with an average of 50 days and percentage of mortality was $59 \%$. The pre-pupal period ranged from 4 to 7 days and averaged 6 days and percentage mortality was $66 \%$.The pupal stage ranged from 5 to 9 days and averaged 8 days and percentage of mortality was $69 \%$.Adult pre-emergence (remain inside cocoon) period ranged from 3-10 days with mean of 8 days and percentage mortality was $74 \%$. The percent of adult emergence was $80 \%$ and the sex ratio percentage was $49.98 \%$.The male and female longevity were with mean of 40 and 68 days, respectively as the mean pre-oviposition period was 11 days, the mean of oviposition period were 50 days and the mean postoviposition period was 7 days. The life cycle for female and male were 71.3 days. The mean number of deposited eggs (fecundity) was 170 eggs/female with fertility of $78.5 \%$. The generation duration ranged from 71 to 159 days about 115 days for males and ranged from 71 to 181 days 143 days for females.

Keyword: RPW, Rhynchophorus ferrugineus (Olivier), biological studies, semi-artificial diet potato.
\end{abstract}

\section{INTRODUCTION}

The red palm weevil, Rhynchophorus ferrugineus (Olivier) (Order: Coleoptera, Family: Curculionidae) was first recorded in Egypt in date palm plantations of Sharkia and Ismailia governorates by (Saleh, 1992). Eggs are laid in the injured leaf petioles of date palm trees. Hatching larvae (grubs) tunnel through the soft wood into the heart of the trunk and feed voraciously causing destruction of the palm where they complete their life cycle. Many generations can be passed in the same palm tree. Therefore, neither grubs nor damage caused can be seen directly. Moreover, a brownish viscous liquid can be seen oozing from small holes in the crown or trunk. Often, the attack by the weevil is discernible only when the palm has been extensively damaged (Nirula, 1956). Laboratory rearing of insects is very important to maintain 
purity, age and sex based selection for carrying out lab and field test for improving the control strategies. The knowledge of insect biology, behavior population dynamics and availability of various stages in bulk amount facilitates in keeping many factors unbiased (Shahina et al., 2009).

Aims of the present study was to evaluate the effect of a new semi-artificial diet (potato diet) on some biological aspects of RPW under a cooling incubator at $30 \pm 1 \mathrm{C}^{\circ}$. and $85 \pm 5 \%$.

\section{III-MATERIAL AND METHODS}

\section{Biological Studies}

The laboratory studies of RPW were conducted in laboratory under controlled conditions during $2011\left(30 \pm 1 \mathrm{C}^{\circ}\right.$ and $\left.85 \pm 5 \%\right)$ in the Plant Protection Department, Faculty of Agriculture, Zagazig University.

Adults of RPW were collected from highly infested palm tree orchards at AboNagi farm ,El-Kassassein ,Ismailia governorate.Insects were then transferred to a rearing room and reared on freshly and soft shreded sugarcane stem tissues as a source of food and oviposition site for adults, plastic boxes $(30 \times 20 \times 15 \mathrm{~cm}$.) with tight fitting perforated covers were staked side by side. The sugarcane pieces were checked daily and replaced with fresh cuttings when necessary.

\subsubsection{Eggs stage}

Eggs were collected by using a fine moistened brush and arranged on filter paper into petri dishes. The eggs were kept in an incubator adjusted at constant temperature of $30 \pm 1 \mathrm{C}^{\circ}$ and $85 \pm 5 \% \mathrm{RH} \%$. Eggs were examined daily and the incubation and hatchability percentage aspects were estimated. Ten replicates (each 10 eggs freshly laid) were used. Both hatchability $\%$ and the incubation period were recorded. (Plate 2).
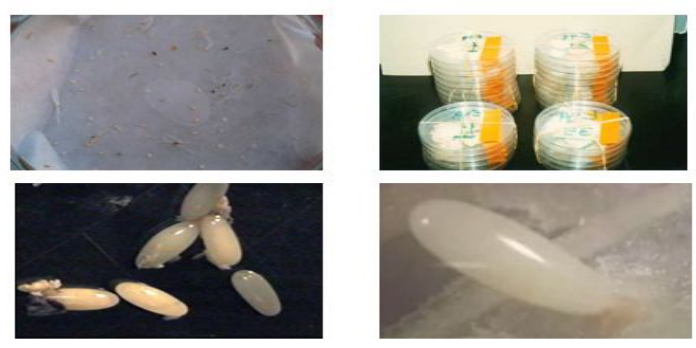

\section{Plate (2): Egg stage}

\subsubsection{Larval stage}

Rearing on semi-artificial diet, according to El-Sebay et al. (2003). The diet contents were as follows; $1 \mathrm{~kg}$ of sweat potatoes, $250 \mathrm{~g}$ fresh carrot, $20 \mathrm{~g}$ glucose, $4 \mathrm{~g}$ casein, $15 \mathrm{~g}$ agar, $250 \mathrm{~g}$ cereals, vitamin $\mathrm{B}(1 \mathrm{mg})$ and vitamin $\mathrm{D}(0.2 \mathrm{mg})$. Contents 
were dissolved in half litter water and mixed carefully together and first stirred in a blinder, then boiled until complete cooking was achieved. Recommended vitamins (B and $\mathrm{D}$ ) were then added on cold diet, the diet was completed with the recommended components and amounts. The diet was left for normal cooling and poured in plastic cups equal in size and kept in a refrigerator.

A total of 100 newly hatched larvae were collected and divided into 10 replicates; each replicate contains 10 newly hatched larvae. The 10 larvae were grouped as follows: By fine brush, from $1^{\text {st }}$ to $3^{\text {th }}$ instars larvae were introduced individually (one larva into rearing plastic tubes and used for rearing larvae of RPW. The sizes of rearing tubes (diameter and height) were $(2 \times 5 \mathrm{~cm}),(4.3 \times 8 \mathrm{~cm})$ and $(7.5 \times 11 \mathrm{~cm})$ for the $1^{\text {st }}, 2^{\text {nd }}$ and the $3^{\text {rd }}$ larval instar where the $4^{\text {th }}, 5^{\text {th }}, 6^{\text {th }}, 7^{\text {th }}, 8^{\text {th }}$, $9^{\text {th }}$ and 10 instars, where transferred in rearing cups Cups were tightly covered with a perforated plastic cover. The food was changed, whenever necessary or consumed. These cups were checked daily, at the end of larval development, some of the palm bark fibers were placed near the larvae to help cocoon formation, (Abd El-Fattah, 2010) (Plates 3 and 4).

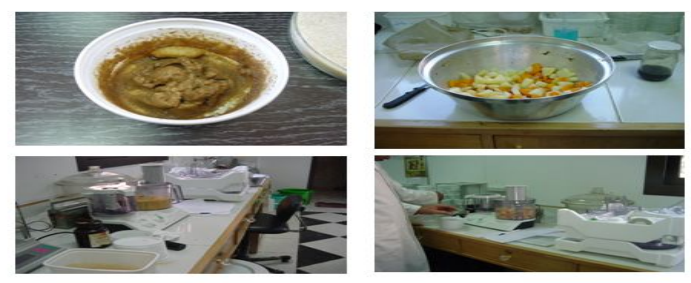

Plate (3): prepaterated semi-artificail diets (potato diet)

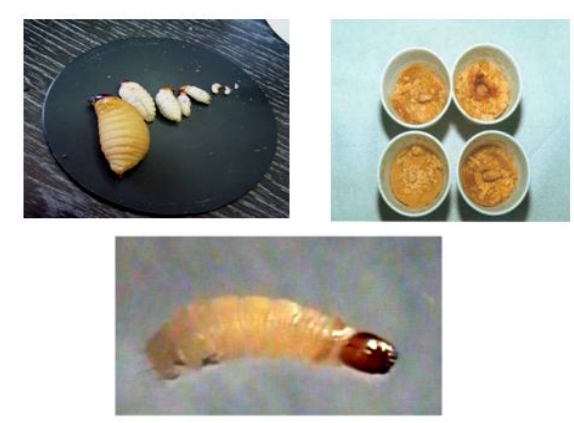

\section{Plate (4): larval stage}

\subsubsection{Pupal stage}

Hundred of full grown larvae, were divided into ten replicates, 10 each, and kept individually in a perforated cylindrical plastic containers $(10 \mathrm{~cm}$ height and $13 \mathrm{~cm}$ diameter) between two layers of a dampish date palm bark fibers and covered with a perforated plastic cover plastic. These containers were placed in the same incubator and daily observed.The inspection of these cocoons was carried out by opening each 
of them from its posterior end during observation and then enclosed (Hussein, 1998).Durations of pre-pupal, pupal and adults remain inside cocoon periods and mortality percentages were calculated and recorded (Plate 5).

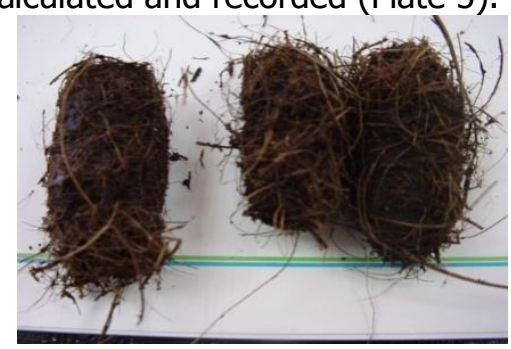

Plate (5): pupal stage

\subsubsection{Adult stage}

Newly emerged adults were taken and each pair (male and female) were put in 1 liter plastic Jars (13 cm. height x $6 \mathrm{~cm}$.diameter).Ten replicates each contained one couple were placed in plastic jars $(13 \mathrm{~cm}$. height $x 6 \mathrm{~cm}$. diameter) and tightly covered with perforated plastic cover. Insects were reared on soft and freshly shreded sugarcane stem tissues as a source of food and ovipositional site for adults. Eggs were collected by using a fine moistened brush and arranged on a moisted filter paper in petri dishes .Numbers of eggs laid by each female were daily counted. Containers were placed carefully in the incubator, pre-ovipostion, ovipostion and post-oviposition periods, longevity of both sexes, fecundity and fertility of adult females, life cycle and generation duration were recorded. (Plate 6 and 7 ).

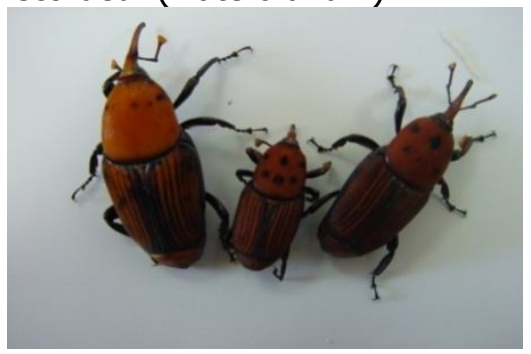

Plate (6): Adult stage

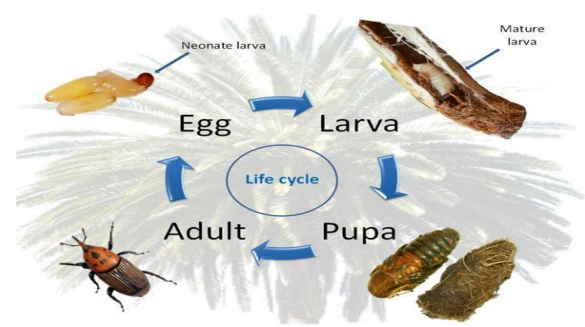

Plate (7): Life cycle of RPW (C.F WaqasWakilet al 2015). 


\section{IV-RESULTS AND DISCUSSION}

\section{Biological studies on RPW, Rhynchophorus ferrugineus (Olivier) (Coleoptera: Curculionidae) reared on semi-artificial diet.}

\subsection{Egg stage}

\subsubsection{Incubation period}

The data presented in Table (1) and Fig.(2) showed that the mean incubation period of RPW eggs under ( $30 \pm 1 \mathrm{C}^{\circ}$.and $85 \pm 5$ R.H.\%) was $3 \pm 0.15$ days, and ranged between 2 to 4 days. Data obtained agreed with those obtained by Rahalkar et al. (1985) ; Alfazairy et al. (2003) and Abd El-Fattah (2010) who found that egg stage of RPW lasted 2-4, 2-3 and $3.09 \pm 0.17$ days when reared on coconut cake and potato diet at $29 \mathrm{C}^{\circ}$.and 60-70 R.H.\%, in the laboratory and $27 \pm 2 \mathrm{C}^{\circ}$.and $75 \pm 5$ R.H.\% .

\subsection{Hatchability}

The mean hatchability percentage of eggs of RPW was $88 \%$ (S.E \pm 1.3 ), Table (1) and Fig.(2) and ranged between 80 to $90 \%$. Data agreed with those obtained by El-Shafie et al. (2013) and Abd El-Fattah (2010) who found that egg hatchability percentage was 88.10 and $81.9 \pm 4.84 \%$ when reared RPW on potato and coconut cake under laboratory conditions, $27 \pm 2 \mathrm{C} .{ }^{\circ}$ and $75 \pm 5$ R.H. \%. Alfazairy, et al. (2003) reported higher value of the hatchability of RPW, averaged $95.3 \% \pm 1.1$ (85.9-100\%) when reared in laboratory conditions on potato diet.

\section{Larval stage}

\subsection{Larval duration}

Results in Table (1) and Fig.(1) showed that larval duration of RPW was (50 \pm 1.06 days ) and ranged between 45 to 55 days. Data agreed with Hussein (1998) and Abd El-Fattah (2010) who found that larval duration of RPW was 51.50 and 45.19 \pm 2.91 days when reared on potato and coconut cake diets in $29 \mathrm{C}^{\circ}$.and 75-90 R.H. \% and $27 \pm 2 \mathrm{C}^{\circ}$.and $75 \pm 5$ R.H. \% under laboratory conditions .Much longer larval duration 127.24 days were obtained by Mahmoud et al. (2015) when RPW reared on potato diet under laboratory conditions ( $29 \pm 1 \mathrm{C}^{\circ}$. and $85 \pm 5$ R.H. \%).

\subsection{Larval mortality percentages}

Data given in Table (1) and Fig. (2) revealed that the mean larval mortality percentage of RPW was $59 \% \pm 2.3$ and ranged between 50 to 70 percent. Data disagree with those reported by Abd El-Fatah (2010) when rearing of RPW under laboratory conditions at $27 \pm 2 \mathrm{C}^{\circ}$ and $75 \pm 5$ R.H.\% on coconut cake diet much lower larval mortality $11 \pm 1.24 \%$.

\section{Cocoonal duration}

The obtained results in Table (1) and Fig.(1) reaveled that the mean pre-pupal period of RPW was ( $6 \pm 0.29$ days) and was ranged from ( $4-7$ days), the mean pupal 
stage of RPW was ( $8 \pm 0.42$ days ) and was ranged from (5 -9 days) and mean adult remain inside cocoon period of RPW was ( $8 \pm 0.68$ days) and was ranged from (3-10 days) Obtained data agreed with Hussein (1998) and Abd El-Fattah (2010) who found that pre-pupal stage of RPW was 7.83 days and mean cocoonal duration was $22.54 \pm 1.30$ days when reared on potato and coconut cake diets in incubator at $29 \mathrm{C}^{\circ}$. and $75-90$ R.H. $\%$ and $27 \pm 2 \mathrm{C}^{\circ}$. and $75 \pm 5$ R.H.\% under laboratory conditions and with those obtained by Mahmoud et al. (2015) who studied that the mean of the prepupal period of RPW was 5.14 days, the means of pupal period were 10.03 days.While adult pre- emergence from cocoon was 9.06 days when rearing RPW on artificial diet (potato diet) under laboratory conditions ( $29 \pm 1 C^{\circ}$.and $\left.85 \pm 5 R . H . \%\right)$.

\subsection{Cocoonal mortality percentages}

Data in Table (1) and Fig.(2) showed that the mean pre-pupal mortality percentage of RPW was $(66 \% \pm 2.67)$ and ranged from 50 to $80 \%$, the mean pupal stage mortality percentage of RPW was $(69 \% \pm 2.77)$ and was ranged from 60 to $80 \%$ and mean adult remain inside cocoon of RPW mortality percentage was (74 \% 2.211 ) and ranged from 60 to $80 \%$. Results agreed with Hussein (1998) who reared RPW on artificial media for three generation at $29^{\circ} \mathrm{C}$ and $75-90$ R.H.\%. The basic ingredients of the artificial diets were sweet potato tubers and found that the highest pupal mortality was $51.61,33.53$ and $23.67 \%$ for the $2^{\text {nd }}$ generation and the $3^{\text {rd }}$ and the $1^{\text {st }}$ generation, respectively Also, Abd El-Fattah (2010) who reared RPW under laboratory conditions $\left(27 \pm 2 \mathrm{C}^{\circ}\right.$ and $75 \pm 5$ R.H.\%) on semi-artificial diet coconut cake diet the cocoonal mortality percentages was $4.0 \pm 2.66 \%$ when reared on potato and coconut cake diets.

\section{Adult stage}

\subsection{Sex ratio}

The obtained data given in Table (1) and Fig.(2) showed that the percentage of male from the total number of emerged adults of RPW was $49.98 \pm 0.08 \%$ and ranged between 33.3 and 66.6\%. Data agreed with Abdel-Fattah (2010) who found that the sex percentage of male was $48.89 \%$ when reared RPW under laboratory conditions (27 2 C. ${ }^{\circ}$ and $75 \pm 5$ R.H.\%) on semi-artificial diet, coconut cake diet and Mahmoud et al. (2015) who found that mean percentage of male emerged was $48.89 \%$ and $47.81 \%$ when reared RPW on artificial diet (potato diet) under laboratory conditions ( $29 \pm 1 \mathrm{C}^{\circ}$.and $85 \pm 5$ R.H.\%).

\subsection{Adult longevity}

\subsubsection{Female longevity}




\subsubsection{Pre-oviposition period}

As showen in Table (1) and Fig.(1) the mean pre-oviposition period of female of RPW was 11 days \pm 1.98 after emergence from the coccon and ranged from 10 to 18 days. Data disagree with those of Alfazairy et al. (2003) who found that the preoviposition period was $2-4$ days and averaged $2.5 \pm 0.2$ days. Kaakeh (2005) studied rearing of RPW at $24 \pm 2 \mathrm{C}^{\circ}$. and $70 \pm 5$ R.H.\%, and a photoperiod of $12: 12$ (L:D) h. on artificial diets of potato and found that the pre-ovipositional periods ranged from 3.15 to 3.61 days. similar values 3.6 \pm 0.37 days obtained by Abd El-Fattah (2010) and 4.80 \pm 1.03 days for El-Shafie et al. (2013).

\subsubsection{Oviposition period}

The average of oviposition period of RPW was 50 days \pm 9.004 ranging from 47 to 80 days. in Table (1) and Fig (1). Data obtained was disagree with those of Kaakeh (2005) who reared RPW in laboratory at $24 \pm 2 \mathrm{C}^{\circ}$. and $70 \pm 5$ R.H.\%, and a photoperiod of 12: 12 (L: D) h. on artificial diets of potato found that the oviposition periods ranged from 3.2 to 3.8 days. Abd El-Fattah (2010) who found that oviposition period of RPW was $80.2 \pm 6.60$ days when reared on coconut cake diet under laboratory conditions ( $27 \pm 2 \mathrm{C}^{\circ}$ and $75 \pm 5$ R. H. \%).

\subsubsection{Post-oviposition period}

Data in Table (1) and Fig. (1) showed that the post-oviposition period of female of RPW was 7 days \pm 1.26 ranging from 5 to 10 days. data obtained agree with Abd El-Fattah (2010) who found that post-oviposition period of RPW was $11.4 \pm 0.87$ days almost twice as much the current study when reared on coconut cake diet under laboratory conditions ( $27 \pm 2$ C. ${ }^{\circ}$ and $75 \pm 5$ R.H.\%).

\subsubsection{Total female longevity}

In respect of mean longevity of adult female, results tabulated in Table (1) and Fig. (1) show that the total female longevity of RPW was 68 days \pm 12.05 and ranged from 65 to 106 days. Data agree with Abd El-Fattah (2010); El-Shafie et al. (2013) and Mahmoud et al. (2015) who found that total female longevity of RPW were $95.2 \pm 6.75,74.8 \pm 2.20$ and 91.2 days when reared on coconut cake and two potato diets under laboratory conditions $\left(27 \pm 2 \mathrm{C}^{\circ}\right.$ and $75 \pm 5$ R.H.\% and $29 \pm 1 \mathrm{C}^{\circ}$. and $85 \pm 5$ R.H. \%).

\subsubsection{Male Longevity}

The average male longevity of RPW was 40 days \pm 7.61 and ranged 37-75 days. In Table (1) and Fig.(1) Data obtained disagree with obtained by Abd El-Fattah (2010) who reared RPW on the semi-artificial diet coconut cake diet under labotatory conditions ( $27 \pm 2$ C. ${ }^{\circ}$ and $75 \pm 5$ R.H.\%) and found that the average of RPW male longevity was $97.8 \pm 5.96$ days .El-Shafie et al. (2013) determined that the mean 
longevity of the males of RPW reared on semi-artificial diet, the potato diet under laboratory conditions was $83.30 \pm 1.63$ days and Mahmoud et al. (2015) who found that male longevity of RPW was 94.6 days when reared on potato diet under laboratory conditions $\left(29 \pm 1 C^{\circ}\right.$.and $85 \pm 5$ R.H. \%).

\subsection{Female fecundity}

Obtained results in Table (1) and Fig. (1) cleared that the mean number of eggs laid by one female (fecundity of female) of RPW was approximately 170 eggs / female \pm 29.14 ranging (170-240 eggs / female). Data obtained agree with Hussein (1998); Salama and Abdel-Razek (2002); El-Shafie et al. (2013) and Mahmoud et al. (2015) who found that female fecundity was 181.0 eggs / female, $184.00 \pm 18.68,181$ and 225.6 eggs when RPW reared one potato diet under laboratory conditions $\left(29 \pm 1 \mathrm{C}^{\circ}\right.$ and $85 \pm 5$ R.H.\%). Results disagree with Abd El-Fattah (2010) who reared RPW under laboratory conditions $\left(27 \pm 2 \mathrm{C}^{\circ}\right.$ and $75 \pm 5$ R.H.\%) on artificial diet coconut cake diet and found that the insect RPW fecundity was $275.0 \pm 23.55$ eggs / female.

\subsubsection{Fertility}

The mean fertility percentage of RPW was $78.5 \% \pm 13.09$ ranging from 94 to 100\%. Table (1) and Fig.(2).Results obtained agreed with Salama and Abdel - Razek (2002) who found that fertility percentage of RPW was $94-100 \%$ when reared on potato diet under laboratory conditions.

\subsection{Life cycle}

Data in Table (1) and Fig. (1) clarified that the total life cycle from egg to egg of RPW was $71.3 \pm 12.019$ days, ranging from 76 to 94 days. Data agree with Abd ElFattah (2010) and El-Shafie et al. (2013) who found that life cycle lasted $74.42 \pm 4.98$ and $82.41 \pm 1.54$ days when RPW reared on coconut cake, potato diets under

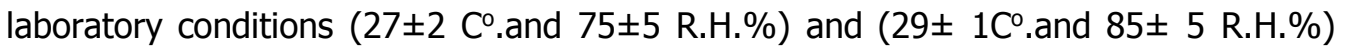
Results obtained disagree obtained by Salama and Abdel-Razek (2002) who found that the duration of the life cycle for males and females of RPW were 164.97 and 194.61 days on semi-artificial diet potato diet in laboratory conditions.

\subsection{Generation duration}

The obtained data in Table (1) and Fig.(1) showed that the mean duration of generation period calculated from the date of eggs deposited to the death of adult of RPW was about $115 \pm 8.5557$ days ranging (71-159 days) and 143 days \pm 12.403 ranging (71-181 days) per males and females, respectively. Data obtained agreed with Abd El-Fattah (2010) who found that generation duration of RPW was 166.02 \pm 9.78 days when reared on coconut cake diet under laboratory conditions (27 $\pm 2 \mathrm{C}^{\circ}$. and $75 \pm 5$ R.H.\%) and results disagreed with obtained by Hussein (1998) who 
mentioned that reared RPW for one generation in incubator at $29^{\circ} \mathrm{C}$. and $75-90$ R.H.\% on potato diet and found that generation duration was about $185 \& 189.3$ days per males and females, respectively.

Table 1. Some biological aspects of the red palm weevil, Rhynchophorus ferrugineus (Olivier) reared at $30 \pm 1^{\circ} \mathrm{C}$. and $85 \pm 5$ R.H.\%.

\begin{tabular}{|c|c|c|}
\hline Biological aspects & Mean \pm S.E. & Range \\
\hline Incubation period of eggs & $3 \pm 0.15$ days & $2-4$ \\
\hline Hatchability (\%) & $88 \% \pm 1.3$ & $80-90$ \\
\hline Larval duration days & $50 \pm 1.06$ days & $45-55$ \\
\hline Total larval mortality \% & $59 \% \pm 2.3$ & $50-70$ \\
\hline Cocoonal period: & $22 \pm 0.931$ days & $15-26$ \\
\hline 1-Pre-pupal period & $6 \pm 0.29$ days & $4-7$ \\
\hline 2-Pupal period & $8 \pm 0.42$ days & $5-9$ \\
\hline 3-Adult remaining & $8 \pm 0.68$ days & $3-10$ \\
\hline \multicolumn{3}{|l|}{ Cocoonal mortality: } \\
\hline 1-Pre-pupal mortality \% & $66 \% \pm 2.67$ & $50-80$ \\
\hline 2-Pupal mortality \% & $69 \% \pm 2.77$ & $60-80$ \\
\hline $\begin{array}{l}\text { 3-Adult remaining inside cocoon } \\
\text { mortality \% }\end{array}$ & $74 \% \pm 2.211$ & $60-80$ \\
\hline Males \% & $49.98 \% \pm 0.08$ & $33.3-66.6$ \\
\hline \multicolumn{3}{|l|}{ Female longevity: } \\
\hline 1-Pre-oviposition period & $11 \pm 1.98$ days & $10-18$ \\
\hline 2-Oviposition period & $50 \pm 9.004$ days & $47-80$ \\
\hline 3-Post-ovipostion period & $7 \pm 1.26$ days & $5-10$ \\
\hline Total longevity & $68 \pm 12.05$ days & $65-106$ \\
\hline Male longevity & $40 \pm 7.61$ days & $37-75$ \\
\hline Egg fertility \% & $78.5 \% \pm 13.09$ & $94-100$ \\
\hline Female fecundity & $170 \pm 29.14$ eggs & $170-240$ \\
\hline Total life cycle & $71.3 \pm 12.019$ days & $76-94$ \\
\hline Generation of male & $115 \pm 8.5557$ days & $71-159$ \\
\hline Generation of female & $143 \pm 12.403$ days & $71-181$ \\
\hline
\end{tabular}

$\%=$ percentage

S.E. $=$ standered error 


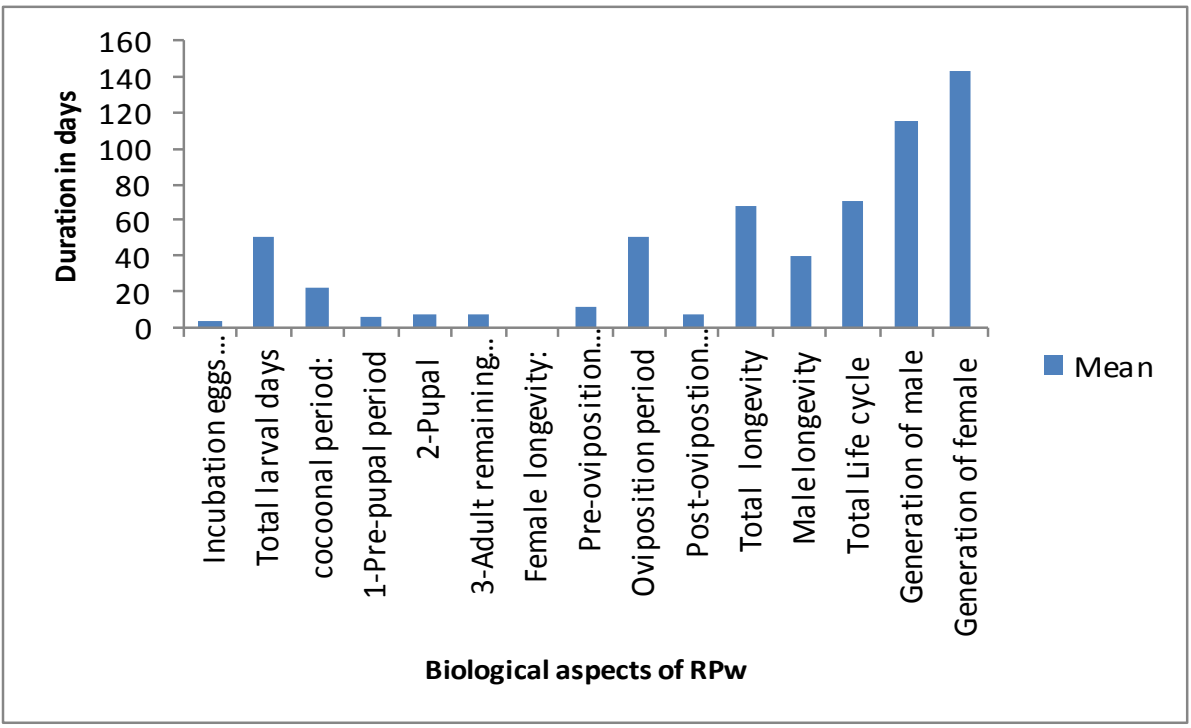

Fig. 1. Some biological aspects of the red palm weevil Rhynchophorus ferrugineus (Oliv.) rearing on semi-artificial diet in controlled cooling incubator at $30 \pm 1 \mathrm{C}^{\circ}$. and $85 \pm 5$ R.H.\%.

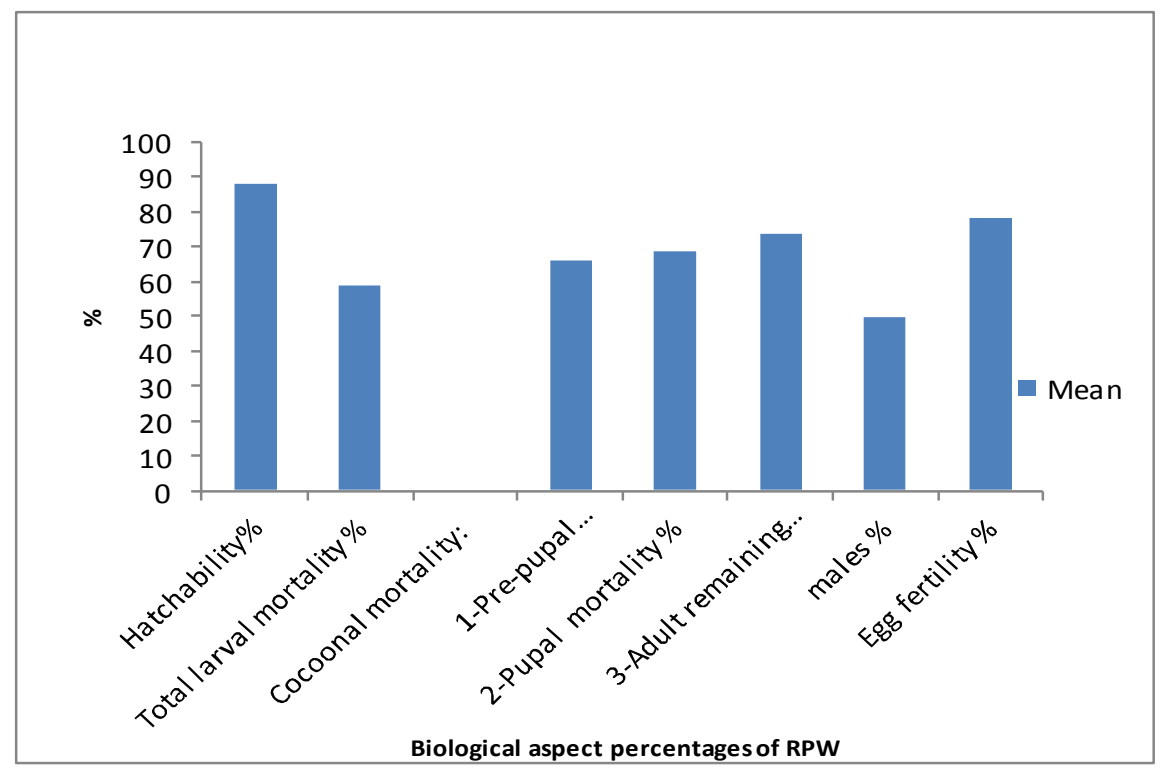

Fig. 2. Some biological aspects percentages of the red palm weevil Rhynchophorus ferrugineus (Oliv.) rearing on semi-artificial diet in controlled cooling incubator at $30 \pm 1 \mathrm{C}^{\circ}$ and $85 \pm 5$ R.H.\%.

\section{REFERENCES}

1. Abd El-Fattah, S.M. 2010. Study of some recent trends on Rhynchophorusferrugineus (Oliv.) infesting date palm trees in Sharkia Governorate. Ph.D.Thesis, Fac. of Agric., Zagazig Univ., 191pp.

2. Alfazairy, A. A.; A.M. EL-Minshawy; H.K. Hedaya and R. Hendi. 2003. An easy and cheap feeding diet of vegetable origin for rearing the red palm weevil, 
Rhynchophorusferrugineus (Olivier) (Coleoptera: Curculionidae). Proceedings of the First Int. Egyptian Romanian Conf., Zagazig, Egypt, Dec., 6-8 ${ }^{\text {th }}: 171-179$.

3. El-Sebay,Y.; M.K.A.El-Latif and T. M. Makhlouf. 2003. Laboratory rearing of red palm weevil, Rhynchophorus ferrugineus. Oliv. (Coleoptera: Curculionidae) on artificial diet. Egyptian J.Agric. Res. ,81(2): 551-554.

4. El-Shafie, H. A. F.; J. R. Faleiro; M.M. Abo-El-Saad andS. M. Aleid. 2013. A meridic diet for laboratory rearing of red palm weevil, Rhynchophorus ferrugineus (Coleoptera: Curculionidae). Scientific Research and Essays, Acad. J.,8 (39):1924-1932.

5. Hussein, K. M.A. 1998. Biological, ecological and control studies on red palm weevil, Rhynchophorus ferrugineus in Sharkia and Ismailia Governorates, Egypt. M.Sc. Thesis, Fac. Agric., Zagazig Univ., 289 pp.

6. Kaakeh, W. 2005. Longevity, fecundity, and fertility of the red palm weevil, Rhynchophorus ferrugineus Olivier (Coleoptera: Curculionidae) on natural and artificial diet. Emir.J.Agric.Sci.,17 (1): 23-33.

7. Mahmoud, M.A.; S.A.Hammad and M.A.E. Mahfouz. 2015. Biological studies on red palm weevil, Rhynchophorus ferrugineus (Olivier) (Coleoptera: Curculionidae) Middle East J. App. Sci.Volum 5(1):247- 251.

8. Nirula, K.K. 1956. Investigations on the pests of coconut palm. IVRhynchophorus ferrugineus F. Indian Coconut J., 9(4): 229-247.

9. Rahalkar,G.W.; M.R. Harwalker; H.D. Rananavare; A.J. Tamhnkar and K. Shantaram. 1985. The biology of red palm weevil, Rhynchophorus ferrugineus Olivier, A handbook of insect rearing, Pritam Singh and R.F.Moore (Eds.). Elsevier Sci. Pub., B.V.Amsterdam, Vol. 1: 279-286.

10. Salama, H.S. and A.S. Abdel-Razek. 2002. Development of the red palm weevil, Rhynchophorus ferrugineus (Oliv.) (Coleoptera: Curculionidae) on natural and synthetic diets .Anzeiger fur Schadlingskunde, 75 (5): 137-139.

11. Saleh, M.R.A. (1992).Red palm weevil, Rhynchophorus ferrugineus (Olivier). The first record for Egypt and indeed the African Continent, List No. 10634 Africa, Collection No. 22563. British Museum Report of International Institute of Entomology, 56 Queen's Gate, London, SW 75 JR UK: 1p.

12. Shahina, F., J. Salma, G. Mehreen, M.I. Bhatti and K. T.Tabassum. 2009. Rearing of Rhynchophorus ferrugineus (Oliv.) in laboratory and field conditions for carrying out various efficacy studies using EPNs, Pak. J. Nematol, 27(2): 221-231.

13. Waqas, W.; J. Flaleiro and T. Mallier. 2015. Sustainable Pest Management in Date Palm: Current Status and Emerging Challenges.Sustainability in plant Crop Protection, Springerlink.:pp 409. 


\section{دراسات بيولوجية على سوسة النخيل الحمر اء

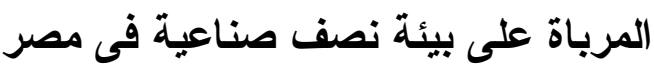

محمد على على الديب 1، منصور محمد منصور الزهيرى 1 محد

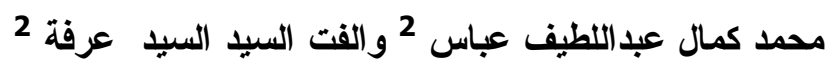

$$
\text { 2- } 1
$$

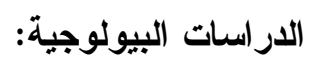

تم تربية حشرة سوسة النخيل الحمر اء داخل الحضان فى حجرة التزبية على بيئة نصف صناعية

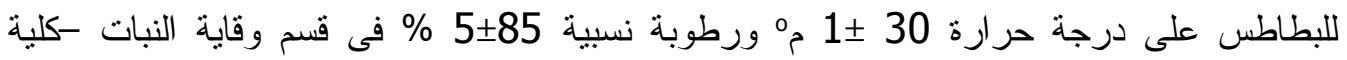
الزر اعة جامعة الزقازيق مصر وملاحظة فتر ات النمو المختلفة للحشرة و نسجيل التالى:

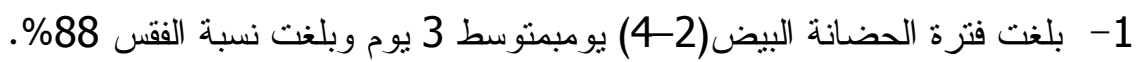

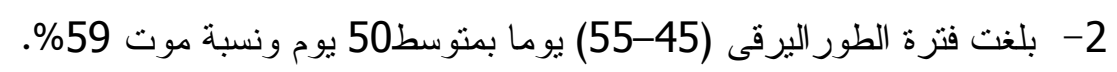

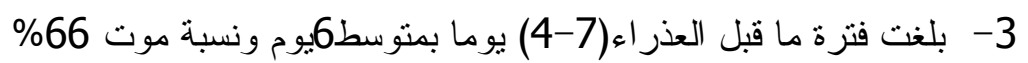

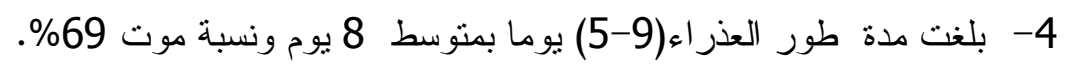

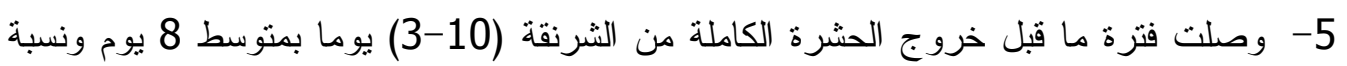
موت 74\%

6- بلغت نسبة خروج الحشرة الكاملة من الثرنقة 80 \% وبنسبة جنسية 98, 49\% (1:1) تقريبا.

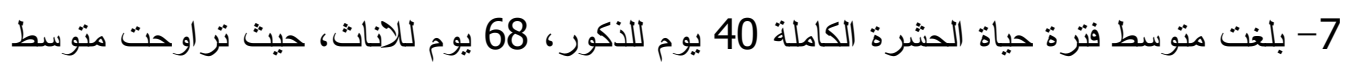
فترة ما قبل وضع البيض11 يوم ومتوسط فتزة وضع البيض 50 يوم ومتوسط فترة ما بعد وضع البيض7 7 يوم. 8- بلغت دورة الحياة 71.3 يوما.

9- كان منوسط أنتاج الانثى من البيض 170 بيضة وبلغت النسبة المئوية لفقس البيض 78.5 بان 10- مدة الجيل بلغت للذكور (71-159 ) يوما بمنوسط 115 يوم وبلغت مدة الجيل للاناث (181 الى 71 ) يوما بمتوسط 143 يوم بلفئ 